\title{
Testicular sex cord stromal tumour with granulosa cell differentiation: detection of steroid hormone receptors as a possible basis for tumour development and therapeutic management
}

\author{
W Düe, K-P Dieckmann, G Niedobitek, G Bornhöft, V Loy, H Stein
}

\begin{abstract}
A testicular sex cord stromal tumour with granulosa cell differentiation, typical of granulosa cell tumours of the adult type, was investigated immunohistologically on snap frozen and paraffin wax embedded material. The predominance of vimentin and the additional expression of cytokeratin subtypes 8 and 18 , as well as the negative staining for epithelial membrane antigen, accorded with results previously reported, for ovarian granulosa cell tumours; the lack of expression of desmoplakin, however, was a distinctive feature. Together with negative staining for leucocyte common antigen, the antigen pattern facilitates the differential diagnosis between granulosa cell tumour and undifferentiated carcinoma or gonadal lymphoma, although its suitability for differentiating within the group of gonadal stromal tumours seems to be limited. The small growth fraction, shown by the monoclonal antibody $\mathrm{Ki}-67$, is typical of the clinical behaviour of granulosa cell tumours. The expression of oestrogen and progesterone receptors, also recently found in testicular Leydig cell tumours, may provoke new approaches to the management of testicular granulosa cell tumours, as well as a new hypothesis on the development of these tumours.
\end{abstract}

Testicular stromal tumours, other than those in the Leydig cell tumour group, are rare. Because they show a considerable variety of histological features, the differential diagnosis within the group of testicular stromal tumours as a whole, as well as of other tumours, including lymphomas and undifferentiated carcinomas, can be difficult. The management of testicular granulosa cell tumours principally comprises local surgery even in cases of metastasis ${ }^{1}$ as radiotherapy or chemotherapy, or both, have only been partially successful in cases of metastatic disease..$^{2-5}$

To our knowledge, the immunohistological determination of intermediate filaments and steroid hormone receptors in a testicular sex cord stromal tumour with granulosa cell differentiation has not been described before.

\section{Case report}

A testicular tumour was obtained by semicastration from an 83 year old patient, who was admitted to hospital with a massively enlarged left testicle. After initial recovery the patient died 18 days after surgery of cardiac failure. Preoperative plasma hormone activities had not been determined, and clinical signs of enhanced hormone stimulation were not observed.

\section{Methods}

Routine stains for conventional microscopical examination included haematoxylin and eosin, periodic acid schiff, reticulin, and fat staining. For immunohistochemical analysis, monoclonal antibodies against cytokeratin (broadbent antibodies KL1; Dianova, Hamburg, West Germany), Lu5, ${ }^{6}$ CK7 against cytokeratin subtype 7, CK18 against cytokeratin subtypes 8 and 18, CK19 against cytokeratin subtype 19 (all from Boehringer, Tutzing, West Germany), BA17 against cytokeratin subtype 19 (kindly donated by Dr TaylorPapadimitriou, London, England), vimentin (V9; Dakopatts, Glostrup, Denmark), desmoplakin (DP 1 \& 2-125; Progen, Heidelberg, West Germany), epithelial membrane antigen (E29; Dakopatts) and the leucocyte common antigen (LC; Dakopatts), as well as monoclonal antibodies against the oestrogen receptor (ER-ICA; Abbott, Wiesbaden, West Germany) and the progesterone receptor (Let64; Dianova) were used. The growth fraction of the tumour cells was determined with the antibody $\mathrm{Ki}-67^{7}$ which detects a proliferationassociated antigen expressed in all states of the cell cycle except $\mathrm{G}_{0}$.

Immunohistological staining on snap frozen as well as on formalin fixed, paraffin wax embedded material was done using the alkaline phosphatase-antialkaline phosphatase staining procedure, as described by Cordell $e t$ $a l^{8}$ and modified by Stein et al. ${ }^{9}$ Immunohistological staining for the oestrogen receptor on $6 \mu \mathrm{m}$ thick frozen sections was done as described previously. ${ }^{10}$ Staining with the monoclonal progesterone receptor antibody Let64 was done on frozen sections fixed in Zamboni's fixative. ${ }^{10} 11$

Paraffin wax sections were dewaxed through xylene, xylene/acetone, and acetone, 
Figure 1 High magnification of testicular sex cord stromal tumour with granulosa cell differentiation. Solid areas predominant comprising tumour cells with pale nuclei, small nucleoli, and poorly defined cell borders. Many tumour cells show nuclear grooves $(A)$ (haematoxylin and eosin). Reticulin fibres were very sparse within the tumour (B). (Gomori).

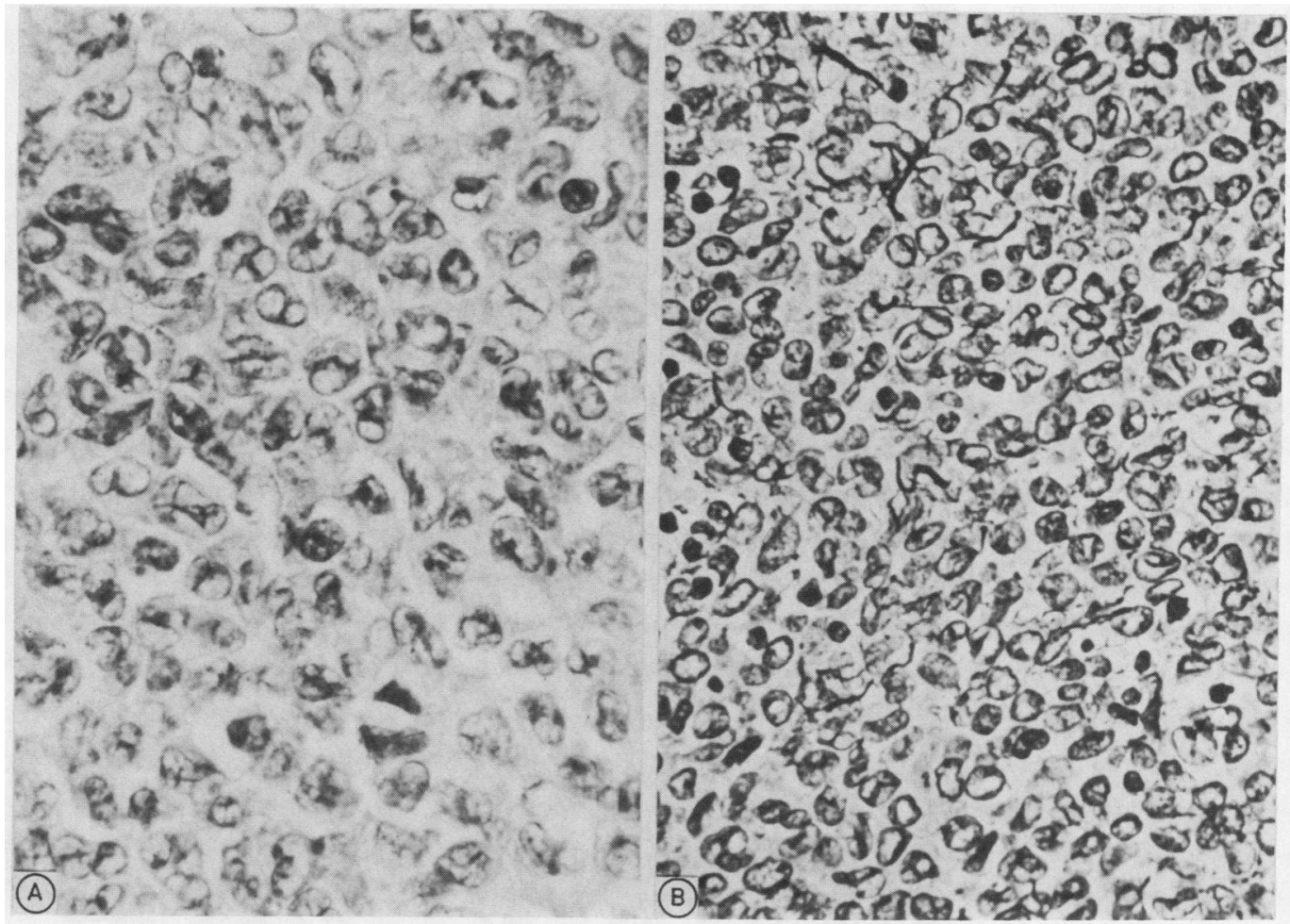

followed by a rinse in TRIS-buffered saline (TBS; 0.05 M TRIS, 0.15 M NaCl, pH 7.6). For the demonstration of the oestrogen receptor, sections were incubated with a $1 \mathrm{mg} / \mathrm{ml}$ solution of protease (Sigma) for 10 minutes at $30^{\circ} \mathrm{C}$ before the primary antibody was applied. Both steroid hormone receptor antibodies were applied for 60 minutes at $37^{\circ} \mathrm{C}$. The oestrogen receptor ICA antibody was used undiluted, while the antibody Let 64 was used in a 1 in 60 dilution. The bound primary antibody was detected, as described previously. ${ }^{89}$
The staining for KL1 on paraffin wax sections, was routinely done without protein digestion. Various proteolytic enzymes were also evaluated for the effect on the staining result. Protease (Sigma, Deisenhofen, West Germany), Pronase (Boehringer, Mannheim, West Germany), proteinase K (Gibco BRL, Eggenstein, West Germany), trypsin (Sigma) and pepsin (Sigma) were used before incubation with the primary antibody in a concentration of $1 \mathrm{mg} / \mathrm{ml}$ diluted with TBS for 15 , 20 , and 30 minutes at $30^{\circ} \mathrm{C}$, respectively.

The antibodies $\mathrm{Ki}-67, \mathrm{DP} 1 \& 2-125$, and
Figure 2 In a few areas tumour cells were arranged in a macrofollicular $(A)$ or microfollicular $(B)$ manner. The cysts were filled by a lightly eosinophilic fluid which was negative for epithelial membrane antigen

(haematoxylin and eosin).

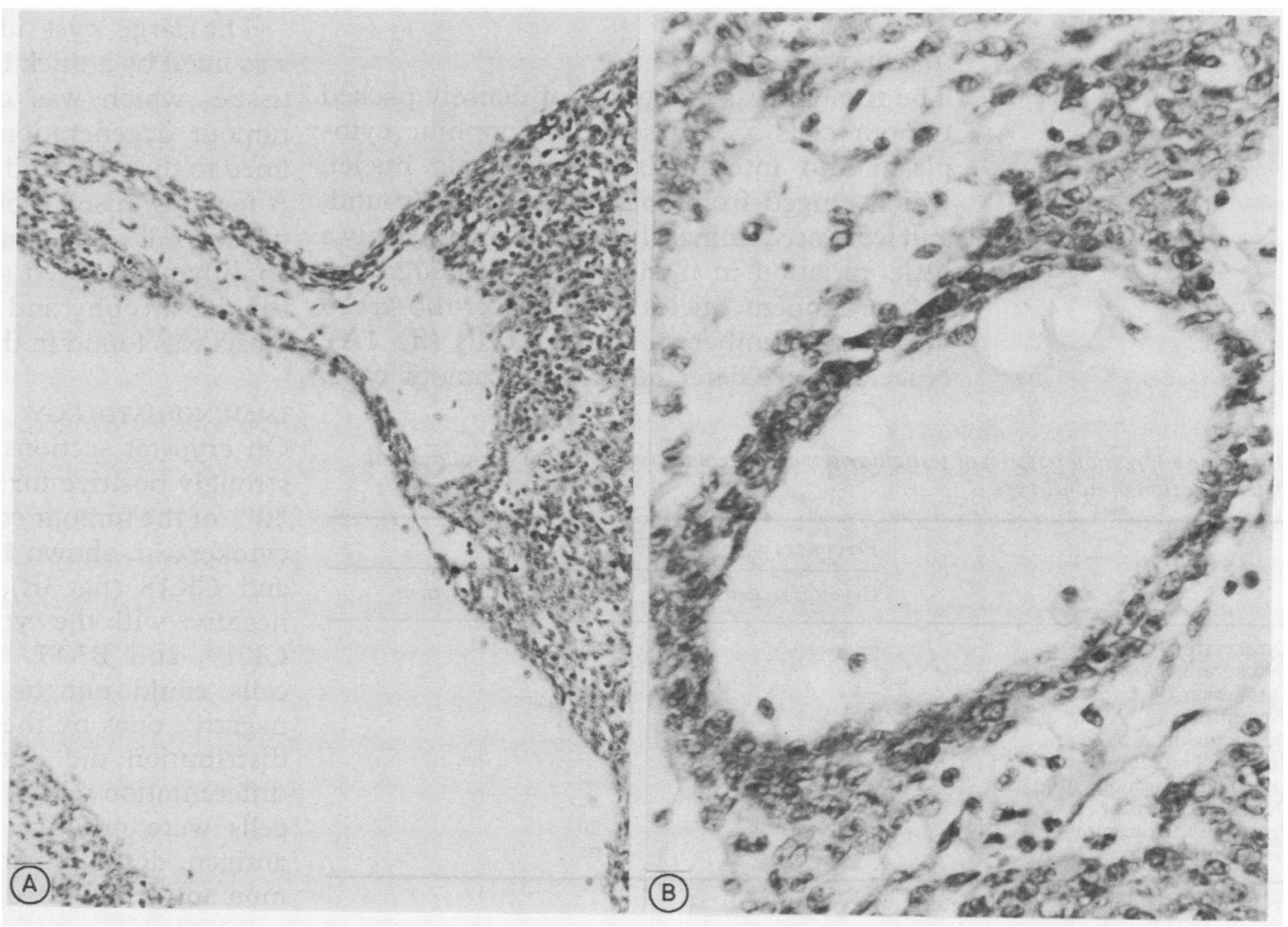


Figure 3 All tumour cells expressed vimentin $(A)$ $(V 9$, cryostat section); expression of cytokeratin was confined to $30^{\circ} \%$ of cytokeratin subtype 18 in this microphotograph $(B)$ (CK18, cryostat section). tumour cells, shown for the

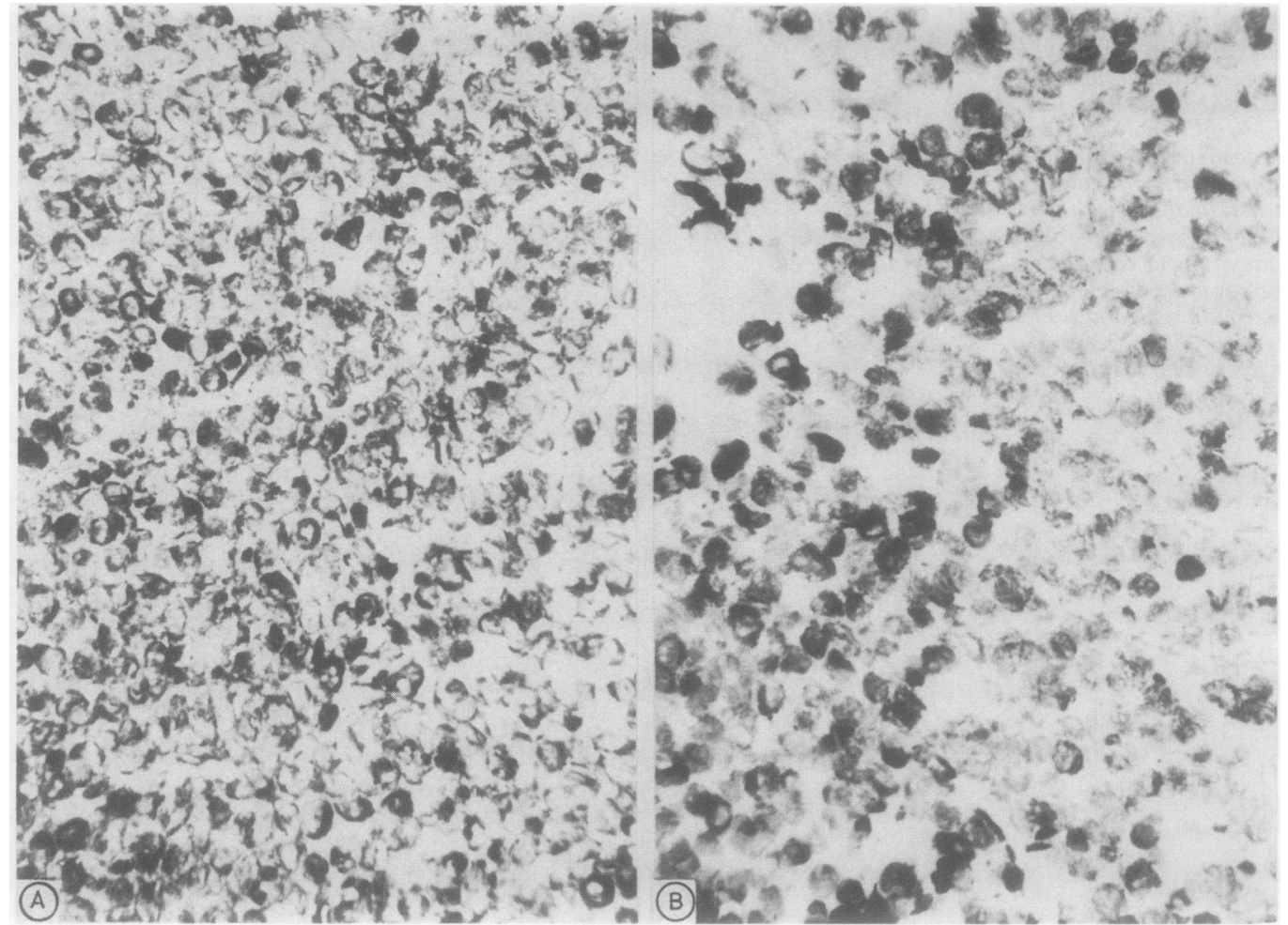

CK7 were only suitable for cryostat sections.

\section{Results \\ MACROSCOPY}

The left testis had been almost completely replaced by a tumour measuring $180 \times 110$ $\times 100 \mathrm{~mm}$. It was composed of solid areas and of a cyst, $100 \mathrm{~mm}$ in diameter, and filled with a muddy, yellowish fluid, due to tumour degeneration. The solid areas showed changes from greyish and glassy in appearance to red, partly due to haemorrhage. The tunica albuginea was intact, and the epididymis did not seem to be affected.

\section{HISTOLOGY}

The tumour was composed of densely packed tumour cells with a scant eosinophilic cytoplasm and intermediate sized, pale nuclei, which ranged from spindle-shaped to round, and were predominantly oval. There was only a little variation in nuclear size. Although not very prominent, nuclear grooves were observed in a large number of tumour cells (fig 1A). Nuceloli were detected in most tumour cells,

Antigenic expression pattern of testicular sex cord stromal tumour with granulosa cell differentiation of adult type

\begin{tabular}{|c|c|c|}
\hline & \multicolumn{2}{|c|}{ Percentage of positive cells } \\
\hline & Cryostat sections & Paraffin wax sections \\
\hline Cytokeratin 7 & - & ns $^{\star}$ \\
\hline Cytokeratins $8+18$ & 30 & - \\
\hline Cytokerain 19 & - & - \\
\hline Vimentin & 100 & 75 \\
\hline Desmoplakin & - & ns \\
\hline Epithelial membrane antigen & - & - \\
\hline Leucocyte common antigen & - & - \\
\hline Oestrogen receptor & 50 & - \\
\hline Progesterone receptor & 75 & 20 \\
\hline Growth fraction & 1 & ns \\
\hline
\end{tabular}

^NS (antibody not suitable for paraffin wax sections). but they were not enlarged. Mitotic figures were seen only occasionally. Cell borders were not visible. The proliferation pattern was solid, with a homogenous distribution of the tumour cells. In smaller areas there was a cystic or macrofollicular arrangement (fig 2A), the cysts being filled with lightly eosinophilic fluid. Clear-cut Call-Exner bodies were not identified, although there were some microfollicular structures (fig 2B). Fat stains showed no intracytoplasmatic lipid droplets. Areas with a different cytomorphology representing a second tumour component were not detected. Reticulin fibres were very sparse (fig 1B).

The large cyst identified macroscopically was lined by a thick layer of hyalinised fibrous tissue, which was confirmed to be due to tumour degeneration. The tumour was confined to the testis and did not infiltrate the rete. A few hyalinised tubules were observed at the border of the tumour. The ipsilateral epididymis showed severe fibrosis. Advanced tubular atrophy and mild Leydig cell hyperplasia was found in the contralateral testis.

\section{IMMUNOHISTOLOGY}

On cryostat sections all tumour cells stained strongly positive for vimentin (fig $3 \mathrm{~A}$ ). About $30 \%$ of the tumour cells additionally expressed cytokeratin, shown by antibodies KL1, Lu5, and CK18 (fig 3B), while the staining was negative with the cytokeratin antibodies CK7, CK19, and BA17. The cytokeratin positive cells could not be distinguished from the negative ones by their morphology, and their distribution did not depend on histological differentation within the tumour. The tumour cells were negative for epithelial membrane antigen, desmoplakin, and the leucocyte common antigen. Oestrogen receptors were detec- 
Figure 4 About $50^{\circ}{ }_{0}$ of the tumour cells expressed the oestrogen receptor within the nucleus on cryostat sections $(A)$ (ER-ICA, cryostat section). The reactivity was more pronounced and partially preserved even on paraffin wax embedded material for progesterone receptors $(B)$ (Let64).

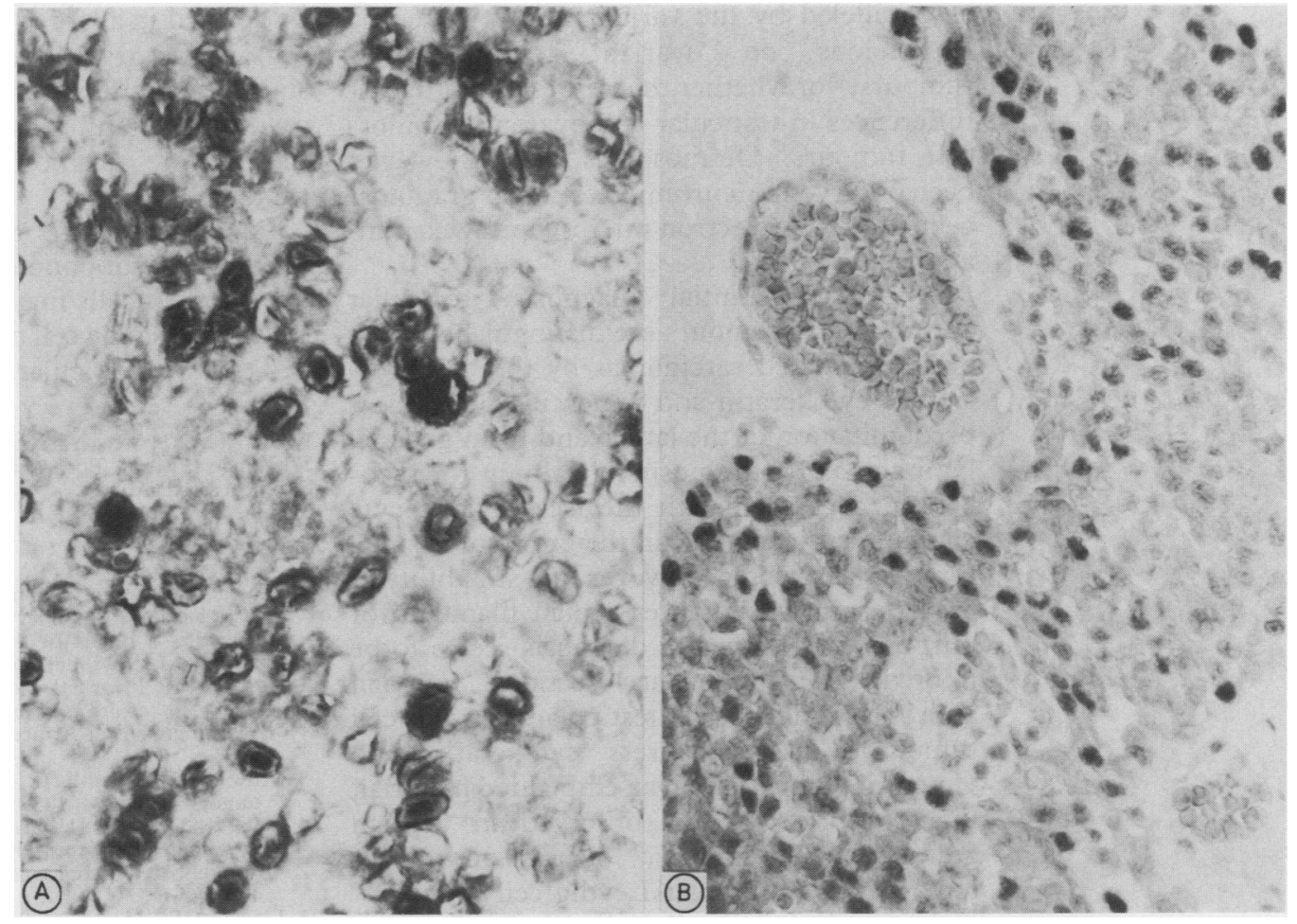

ted in the nuclei of half the tumour cells (fig $4 \mathrm{~A}$ ), and progesterone receptors in $75 \%$. The intensity of the reaction was moderate to strong compared with the results obtained on breast carcinomas in our laboratory. The growth fraction, as determined with the antibody $\mathrm{Ki}$ 67 , was about $1 \%$ (table).

The reactivity for cytokeratin and oestrogen receptors on paraffin wax sections was totally lost, while it was reduced for vimentin and progesterone receptors. Nevertheless, vimentin was strongly expressed in about $75 \%$ of the tumour cells. The distribution of progesterone positive tumour cells was somewhat patchy. In the framework of the tissue on the whole slide the fraction of positive cells was about $20 \%$, while progesterone receptors were detected in $50 \%$ of the tumour cells in those areas in which the reaction was preserved (fig 4B). Again, the tumour was totally negative for the epithelial membrane and leucocyte common antigens.

For the cytokeratin antibody KL1, additional protein digestion of paraffin wax sections showed no positive staining reaction for any condition under study. Instead the reaction was diminished in the rate epithelium after incubation with pepsin or trypsin for 20 minutes, and for protease after 30 minutes of incubation.

\section{Discussion}

Testicular stromal tumours other than those of the Leydig cell tumour group comprise less than $2 \%$ of all testicular tumours. ${ }^{21213}$ These are therefore, considerably less common than their ovarian counterparts. ${ }^{14}$ Based on cytological and histological characteristics, the case presented in this study was classified as a sex cord stromal tumour with granulosa cell differentiation, because it fulfilled all the criteria of a pure granulosa cell tumour of the adult type except for the lack of typical CallExner bodies. This tumour type subpopulation has been estimated to comprise about $15 \%$ of gonadal stromal tumours, ${ }^{15} 16$ with a peak incidence during the first months of life, ${ }^{15-19}$ and mainly showing the histological features of juvenile granulosa cell tumours. Adult type testicular granulosa cell tumours are therefore exceedingly rare. About $10 \%$ of testicular granulosa cell tumours are malignant. ${ }^{2}$

Our results on intermediate filament expression agree with those previously reported for ovarian granulosa cell tumours. ${ }^{20-23}$ Coexpression of cytokeratin and vimentin has been found on cryostat sections of ovarian granulosa cell tumours ${ }^{23}$; paraffin wax embedded sections were partially cytokeratin negative. ${ }^{20-22}$ The assumption that these differences are at least partially due to fixation methods, as suggested by Czernobilsky et $a l,{ }^{23}$ is supported by our results, which allow a direct comparison of intermediate filament detectability on the same tumour under different conditions of tissue processing. Furthermore, the detection of cytokeratin subtypes 8 and 18 coincides with results on immunoblotting ${ }^{23}$ and those previously obtained with antibody CAM $5 \cdot 2$ against cytokeratin subtypes 8,18 , and $19^{22}$ on ovarian granulosa cell tumours. According to our results, the reactivity is not due to cytokeratin subtype 19 . The negativity for cytokeratin even after protein digestion of paraffin wax sections differs from the results reported by Benjamin et $a l^{2}$ and may be due to different epitopes which react with the antibodies $\mathrm{KLl}$ and CAM 5.2.

The main divergence from the results of Czernobilsky et $a l^{3}$ on ovarian granuloma cell our case, although the same antibody DP $1 \& 2$ 125 was used. Further evaluation is therefore needed to determine whether this is incidental, tumours is the negativity for desmoplakin in 
as paralleled by the variations in cytokeratin expressions on ovarian granulosa cell tumours, ${ }^{22}$ or whether this represents antigenic differences in testicular and ovarian granulosa cell tumours. Desmosomes have, however, been observed in a juvenile testicular granulosa cell tumour by electron microscopical examination. ${ }^{24}$

As to differential diagnosis, testicular granulosa cell tumours are distinguished from undifferentiated carcinomas by the coexpression of cytokeratin and vimentin with a clear predomination of the latter, and from gonadal lymphomas by the positive staining for cytokeratin combined with the lack of leucocyte common antigen. Within the group of stromal tumours as a whole, however, the suitability of the determination of intermediate filaments for purposes of differential diagnosis seems to be limited. On cryostat sections ovarian androblastomas ${ }^{25}$ and testicular Leydig cell tumours $^{26}$ also coexpress cytokeratin and vimentin. On paraffin wax embedded material, this coexpression was observed in ovarian granulosa cell tumours, ${ }^{22}$ ovarian androblastomas, ${ }^{2122} 27$ testicular Leydig cell tumours ${ }^{26}$ and normal testicular Sertoli cells. ${ }^{28}{ }^{29}$ Furthermore, the reactivity, particularly for cytokeratin antibodies, is, in our experience, ${ }^{26} \mathrm{con}$ siderably reduced for Leydig cell tumours, which results in cytokeratin negative cases in the ovary ${ }^{2125}$ and the testis. ${ }^{2126}$ This, again, is paralleled by the staining results of a subgroup of ovarian ${ }^{202228}$ and testicular granulosa cell tumours.

Data about endocrinological activity in testicular granulosa cell tumours are very sparse. Some cases, however, have been reported to be associated with gynaecomastia or increased excretion of urinary oestrogen. ${ }^{131730}$ The presence of oestrogen or progesterone receptors, as found in our case, has, to our knowledge, not been previously reported. In a recent immunohistochemical study we also found both receptors in four out of five testicular Leydig cell tumours, ${ }^{26}$ which explained the experimental induction of Leydig cell tumours by the application of oestrogens. ${ }^{31-37}$ Thus there is a subgroup of gonadal stromal tumours which may be sensitive to oestrogenic and, therefore to anti-oestrogenic action, and this is obviously not restricted to Leydig cell tumours.

Although no direct conclusion can be drawn from our case about advanced ovarian granulosa cell tumours which are more aggressive, the results presented here may have some implications for the management of granulosa cell tumours in cases of metastasis, as, although combined chemotherapy has been successful in some cases of stage III ovarian granulosa cell tumours, ${ }^{34}$ failures have also been observed. ${ }^{412}$ Against this background, the data about chemotherapy in gonadal stromal tumours, and particularly in testicular granulosa cell tumours, are not sufficient for definite conclusions to be drawn about the best treatment in cases of metastatic disease. ${ }^{12438}$ Our results on hormone receptors could thus give rise to new therapeutic approaches, if these results can be verified in a larger number of cases, including ovarian granulosa cell tumours of various stages. Determination of steroid receptors on cryostat sections is therefore desirable during the routine diagnosis of testicular stromal tumours.

Furthermore, the recently proposed hypothesis that a subpopulation of oestrogen receptor enriched cells may initiate development of testicular Leydig cell tumours ${ }^{26}$ could be extended to other testicular stromal tumours.

We thank Mrs H Steeger, K Stamatoukou, M Thiel, I Winter, A Schellmann, Mr D Born and L Oehring for their excellent technical assistance.

1 Mostofi FK. Editorial comment to: Kaplan GW, Cromie WJ, Kelalis PP, Silber I, Tank ES. Gonadal stromal tumours: a report of the prepubertal testicular tumor tumours: a report of the prepub

2 Mostofi FK, Price EB. Tumors of the male genital system. Atlas of tumor pathology. Second series, fascicle 8. Washington DC: Armed Forces Institute of Pathology, 1973.

3 Schwartz PE, Smith JP. Treatment of ovarian stromal tumors. Am J Obstet Gynecol 1976;125:402-8.

4 Zaloudek C, Norris HJ. Sertoli-Leydig tumors of the ovary. A clinicopathologic study of 64 intermediate and poorly differentiated neoplasms. Am J Surg Pathol 1984;8: 405-18.

5 Lusch CJ, Mercurio TM, Runyeon WK. Delayed recurrence and chemotherapy of a granulosa cell tumor. Obstet Gynecol 1978;51:505-7.

6 Overbeck VJ, Stähli C, Gudat F, et al. Immunohistological characterisation of an anti-epithelial monoclonal antibody (mAB lu-5). Virchows Arch (Pathol Anat) 1985;407:1-12.

7 Gerdes J, Lemke H, Baisch $\mathrm{H}$, et al. Cell cycle analysis of a cell proliferation-associated human nuclear antigen defined by the monoclonal antibody $\mathrm{Ki}-67$. J Immunol 1984;133:1710-5

8 Cordell JL, Falini B, Erber WN, et al. Immunoenzymatic labelling of monoclonal antibodies using immune complexes of alkaline phosphatase and monoclonal antialkaline phospatase (APAAP) complexes. J Histochem Cytochem 1984;32:219-29.

9 Stein $\mathrm{H}$, Gatter K, Asbahr H, Mason DY. Use of freezedried paraffin-embedded sections for immunohistologic staining with monoclonal antibodies. Lab Invest staining with

10 Gerdes J, Pickartz H, Brotherton J, Hammerstein J, Stein H. Growth fractions and estrogen receptors in human breast cancers as determined in situ with monoclonal antibodies. Am J Pathol 1987;129:486-92.

11 Stefani M, De Martino C, Zamboni L. Fixation of ejaculated spermatozoa for electron microscopy. Nature 1967;216:173-4.

12 Eble JN, Hull MT, Warfal A, Donohue JP. Malignant sex cord-stromal tumor of testis. J Urol 1984;131:546-50.

13 Talerman A. Pure granulosa cell tumour of the testis. Appl Pathol 1985;3:117-22.

14 Scully RE. Tumors of the ovary and maldeveloped gonads. Atlas of tumor pathology. Second series, fascicle 16. Atlas of tumor pathology. Second series, fascicle 16.
Washington, DC: Armed Forces Institute of Pathology, 1979.

15 Kaplan GW, Cromie WJ, Kelalis PP, Silber I, Tank ES. Gonadal stromal tumors: a report of the prepubertal testicular tumor registry. $J$ Urol 1986;136:300-1.

16 Uehling DT, Smith JE, Logan R, Hafez G-R. Newborn granulosa cell tumor of the testis. J Urol 1987;138:385-6.

17 Lawrence WD, Young RH, Scully RE. Juvenile granulosa cell tumor of the infantile testis. A report of 14 cases. Am J Surg Pathol 1985;9:87-94.

18 Young RH, Lawrence WD, Scully RE. Juvenile granulosa cell tumor-Another neoplasm associated with abnormal chromosomes and ambiguous genitalia. A report of three cases. Am J Surg Pathol 1985;9:737-43.

19 Raju U, Fine G, Warrier R, Kini R, Weis L. Congenital testicular juvenile granulosa cell tumor in a neonate with testicular juvenile granulosa cell tumor in a neonate
$\mathrm{X} / \mathrm{XY}$ mosaicism. Am J Surg Pathol 1986;10:577-83.

20 Miettinen M, Lehto V-P, Virtanen I. Expression of intermediate filaments in normal ovaries and ovarian epithelial, sex cord-stromal, and germinal tumors. Int J Gynecol Pathol 1983;2:64-71.

21 Miettinen $M$, Wahlstrom $T$, Virtanen I, Talerman A, Astengo-Osuna $\mathrm{C}$. Cellular differentiation in ovarian sexcord-stromal and germ-cell tumors studied with antibodies to intermediate-filament proteins. $\mathrm{Am} J$ Surg Pathol 1985;9:640-51.

2 Benjamin E, Law S, Bobrow LG. Intermediate filaments cytokeratin and vimentin in ovarian sex-cord stromal tumours with correlative studies in adult and fetal ovaries. J Pathol 1987;152:253-36.

23 Czernobilsky B, Moll R, Leptien G, Schweikhart G, Franke WW. Desmosomal plaque-associated vimentin filaments in human ovarian granulosa cell tumors of various histologic patterns. Am J Pathol 1987;126:476-86. 
24 Pinto MM. Juvenile granulosa cell tumor of the infant testis: case report with ultrastructural observations. Pediatr Pathol 1985;4:277-89.

25 Düe W, Pickartz H, Gerdes J, Stein H. Die Bedeutung des Nachweises von Intermediärfilamenten und epitelialem Membrane-Antigen für die Differrentialdiagnose und die histogenetische Differenzierung von Ovarialtumoren. Verh Disch Ges Pathol 1986;70:295-9.

26 Düe W, Dieckmann K-P, Loy V, Stein H. Immunohistological determination of oestrogen receptor, progesterone receptor, and intermediate filaments in Leydig cell tumours, Leydig cell hyperplasia, and normal Leydig cells of the human testis. J Pathol 1989;157:225-34.

27 Fox H. Sex cord-stromal tumours of the ovary. J Pathol 1985;145:127-48.

28 Miettinen $M$, Virtanen I, Talerman A. Intermediate filament proteins in human testis and testicular germ-cell

29 Düe W, Loy V. Evidence of interepithelial seminoma spread into the rete testis by immunostaining of paraffin sections with antibodies against cytokeratin and vimentin. Urol Res 1988;16:389-93.

30 Marshall FF, Kerr WS, Kliman B, Scully RE. Sex cordstromal (gonadal stromal) tumors of the testis: a report of 5 cases. J Urol 1977;117:180-4.

31 Bonser GM, Robson JM. The effect of prolonged oestrogen administration upon male mice of various strains: development of testicular tumours in the strong A strain. $J$ Pathol Bacteriol 1940;51:9-22.

32 Zimniski SJ, Melner MH, Puett D. Induction of an estrogen-dependent early steroidogenic lesion in murine
Leydig tumor cells. Endocrinology 1985;116:2583-91.

33 Noguchi S, Nishizawa Y, Takatsuka D, Sato B, Matsumoto $\mathrm{K}$. Stimulative effects of estrogen on tumor growth an 5 alpha-steroid production in a mouse Leydig cell tumor line (T124958-R). Cancer Res 1986;46:573-6.

34 Hooker CW, Pfeiffer CA. The morphology and development of testicular tumors in mice of the A strain receiving estrogens. Cancer Res 1942;2:759-69.

35 Berns MJJ, Brinkmann AO, Rommerts FFG, Mulder E, Van der Molen HJ. Changes of oestrogen receptor levels in Leydig cells from mice and rats during culture. J Steroid Biochem 1985;22:293-8.

36 Andervont HB, Shimkin MB, Canter HY. The growth of estrogen-induced interstitial-cell tumors in $\mathrm{BALB} / \mathrm{c}$ mice. estrogen-induced inters

37 Sato B, Miyashita Y, Maeda Y, Noma K, Kishimoto S, Matsumoto $K$. Effects of estrogen and vanadate on the proliferation of newly established transformed mouse Leydig cell lin in vitro. Endocrinology 1987;120:1112-20.

38 Morse MJ, Whitmore WF. Neoplasms of the testis. In: Walsh PC, Gittes RF, Perlmutter AD, Stamey TA, eds. Campbell's Urology. Vol 2. Fifth edn. Philadelphia: WB Saunders 1986:1535-820. 